\title{
Application of Lampung Traditional Dance Assessment Instruments in Rudat Dance Assessment
}

\author{
Indra Bulan $^{1}$, Dwiyana Habsary ${ }^{2}$, Afrizal Yudha Setiawan ${ }^{3}$ \\ \{indra.bulan@fkip.unila.ac.id ${ }^{1}$, habsary.dwiyana@fkip.unila.ac.id², Afrizal.yudha@fkip.unila.ac.id $\left.{ }^{3}\right\}$
}

Dance Education, Lampung University, Bandar Lampung, Indonesia ${ }^{1,2,3}$

\begin{abstract}
Assessment instruments in Lampung traditional dance have not been found for a long time, so that their application in learning arts has not been written and meticulous. The assessment instruments that have been used to assess Lampung traditional dances are Javanese indicators, namely wiraga, wirama, and wirasa. Based on previous research and writings, the assessment instrument for traditional Lampung dances has been analyzed and compared with the Javanese and Balinese assessment instruments. The research shows that there are similarities and differences between the three instruments from the three provinces. This paper intends to see the application of the Lampung traditional dance assessment instrument in the Rudat dance assessment, so that it can be seen how it works. Thus, this assessment instrument can be more qualified and stronger and the weaknesses and strengths can be identified and can continue to be improved. In addition, the existence of an assessment instrument for traditional Lampung dances also strengthens scientific knowledge in the field of assessment in the field of dance, especially in Lampung. With the existence of the Lampung Traditional Dance assessment instrument, it is also a Lampung identity that can be used as a reference in the development of an assessment of traditional Indonesian and international dances.
\end{abstract}

Keywords: Assessment instrument, Lampung traditional dance.

\section{Introduction}

Dance Education is a Sudi Program whose output produces prospective dance teachers or cultural arts teachers. In this case, the Dance Education Study Program of FKIP University of Lampung, which is the first Sendratasik Study Program in Lampung and is the only one in a state university (PTN). This certainly gives a big responsibility to the Dance Education Study Program to continue to preserve, maintain and develop cultural arts in Lampung, especially dance.

Lampung is a very unique province with a wide variety of crafts in it, both natives and immigrants. Of course this presents its own challenges for Lampung, how to maintain Lampung's original cultural arts and develop amidst the plurality of society. Apart from being a challenge, the diversity of cultural arts in Lampung is also an opportunity for research.

Researchers have not researched and written many cultural arts in Lampung. One of the urgent researches to be carried out is related to the assessment instrument of Lampung traditional dance. So far, both lecturers, teachers, and also research conducted using Javanese assessment instruments, namely wiraga, wirama, and wirasa [1].

The instrument for evaluating traditional Lampung dance has been found since 2015 . However, it was only written in book form in 2016 and still needs continuous improvement until now [2]. As for indicators of assessment of traditional Lampung arts that have been found, 
namely, upo, bagho, and ghaso. This assessment indicator has been carried out a comparative analysis with the Java and Bali assessment indicators. Based on the results of the comparison, there are similarities and differences between the three instruments from the three provinces.

This Lampung traditional dance assessment instrument has indeed been invented and written and has been devoted to teachers throughout Lampung. However, its application in real Lampung traditional dance assessment has never been analyzed in more depth. For this reason, this paper intends to analyze how the application of Lampung traditional dance instruments to the assessment of Rudat dance, which is included in the type of traditional Lampung dance. By looking at the three elements, namely upo, bagho, and ghaso.

\section{Research Methods}

The R \& D method focuses on the learning outcomes of Dance Education students by using traditional Lampung dance assessment instruments, namely upo, bagho, and ghaso. Description of quantitative data, namely the calculation of score from the results of the instrument trial to determine its validity and reliability, and supported by qualitative data from interviews and documentation [3].

\section{Results and Discussion}

Assessment (from a language point of view) according to Nurgiyantoro, the assessment is also determined by the current curriculum at that time [4]. However, according to Sudjana assessment is the process of determining the value of an object [5]. This means that the assessment is carried out after the object has done something that can be analyzed the results. The use of self-assessment is for decision making and for accountability for an activity that has been carried out. Assessment of dance learning outcomes is highly subjective. But if the assessment carried out is an assessment of her dancing ability (dances) in terms of the world of education, it is often called psychomotor abilities.

Psychomotor abilities do allow for subjective judgments to occur [6]. However, psychomotor assessments can be observed directly by following predetermined and established indicators as needed. If according to Sudarsono the assessment in dance includes three things, namely Wiraga, Wirama, and Wirasa, but this indicator is not necessarily acceptable and in accordance with Lampung traditional dance [7]. As an assessment, the Surakarta style dance is called Hasta Sawanda, which consists of Pacak, Pancat, Caterpillar, Luwes, Lulut, Wilet, Irama, and Gendhing. Broadly speaking, you can group Pacak, Lulut, Wilet including Wiraga, Pancat, Caterpillar, Luwes including Wirasa and Irama, Gendhing including Wirama.

Just as Java and Bali have their own indicators in assessing their dance as well as Lampung which also has its own assessment indicators. Namely upo which means a pose or body shape in the form of visible motion. Bagho means someone's ability to hear which is closely related to dance accompaniment for movement. Ghaso means suitability and sensitivity that a person has in harmonizing movements with accompaniment according to the concept of dance. Lampung's assessment indicators are also in line with the assessments used by teachers, lecturers, and student teacher candidates in assessing dance. Namely that the assessment of the dance at the time of the demonstration includes wiraga, which means the pose or body shape in carrying out the movement. Wirama means the suitability of dancing body movements with accompanying 
rhythms. Wirasa means the suitability and harmony of body movements with accompaniment which is related to the intentions and roles of dance [6].

Rudat Dance is one of the materials in the Lampung Pepadun Dance course. Rudat dance itself is a traditional dance that has developed and is almost extinct in the area of Labuhan Ratu Village, East Lampung, Lampung Province. Rudat dance is usually danced by men at the night before the meghiyan ngarak event the next day [8]. This dance is performed as a form of entertainment and fills the night before the marriage ceremony is performed. This dance has only been taught this semester with courses which is also new in the 2019 curriculum.

As it is known, lectures in the even semester in 2020 were conducted offline for 5 meetings and the rest online. This certainly affects the form of the assessment carried out. If usually the assessment is carried out in person, this time the assessment is done virtually using videos sent by each student individually.

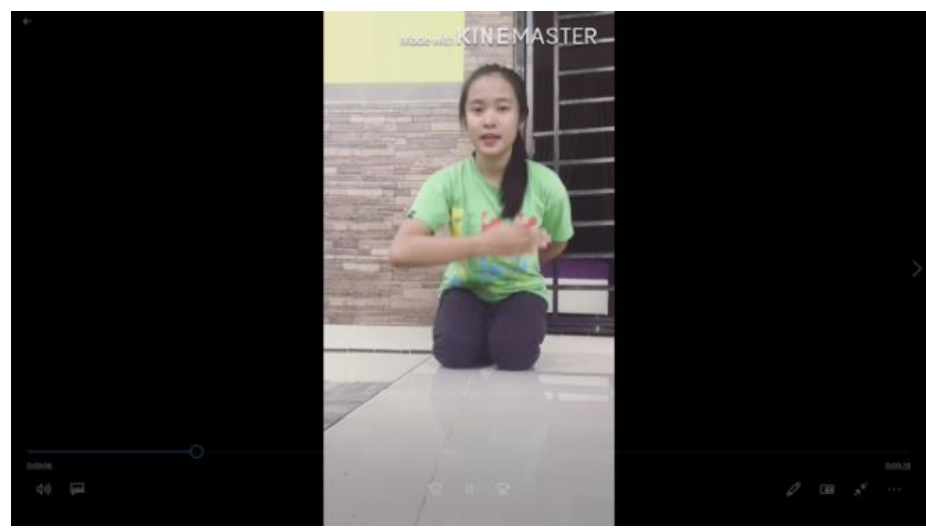

Fig 1. Students move the initial movements of the rudat dance

In Figure 1, it can be seen that students are dancing the initial movements of the Rudat dance. Based on the video sent by the student for this initial motion (motion 1), the student is good enough in moving the rudat dance. In general, as many as 37 students, almost all of them have been able to move this movement 1 quite well.

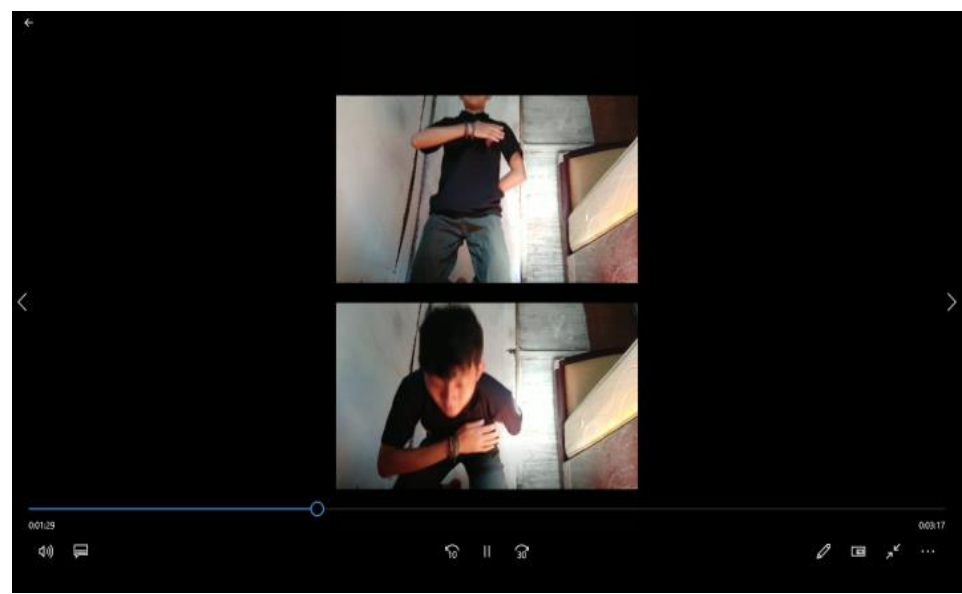

Fig 2. Students move the initial movements of the Rudat dance 
In Figure 2, it can be seen that students are moving movement 3 in the Rudat Dance. In the picture, there are 2 slides, first the student sits and then the student stands on their knees which is done alternately. This movement should be carried out by more than one dancer so that you will see alternating movements. In accordance with the video sent by the students, it is in accordance with the motion technique 3 in the Rudat dance. In general, almost all students can move motion 3 according to their movement technique.

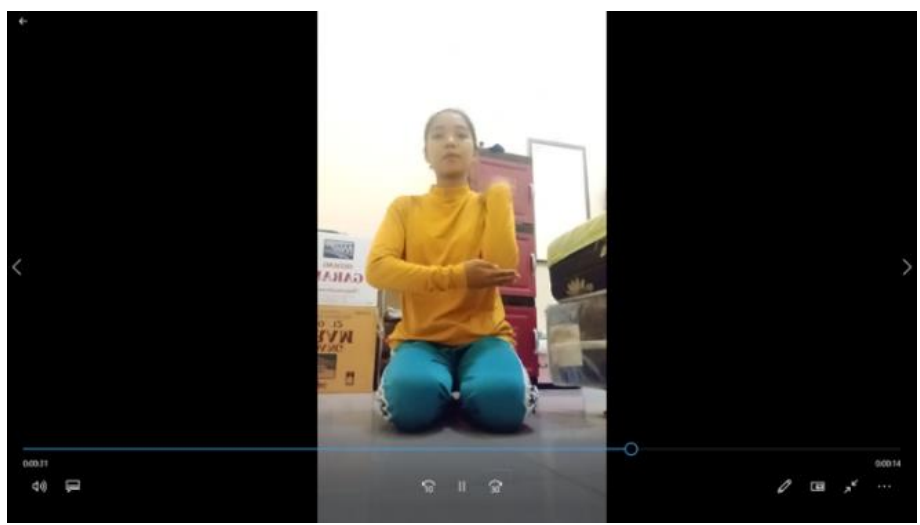

Fig 3. Students move motion 4 in Rudat Dance

In Image 3, it can be seen that students are moving motion 4 in Rudat Dance. Based on the video sent by the student, he has not been able to move motion 4 in the Rudat dance according to the movement technique.

In accordance with the video sent by the students, the upo indicator for memorizing the movements has been sufficiently mastered, but the techniques have not been mastered well. For bagho, the tempo and rhythm of the movements carried out are still not in accordance with the tempo and rhythm of the rudat dance. Likewise for ghaso, students have not been able to harmonize the abilities of upo and ghaso.

Table 1. Student scores with the Upo indicator

\begin{tabular}{cclc}
\hline NO & NPM & \multicolumn{1}{c}{ NAME } & UPO \\
\hline 1 & 1913043001 & Indika Oktafiani & 63 \\
2 & 1913043002 & Elda Savira & 78 \\
3 & 1913043006 & Diana Mai Sari & 60 \\
4 & 1913043007 & Etika Witantri & 61 \\
5 & 1913043008 & Sairul Anwar & 61 \\
6 & 1913043009 & Ahmad Faisal Akbar & 73 \\
7 & 1913043011 & Retno Anisa Putri & 65 \\
8 & 1913043017 & Okta Berliana & 75 \\
9 & 1913043018 & Denta Pramana Putra & 76 \\
10 & 1913043021 & Rara Ardelia Artanti & 67 \\
11 & 1913043023 & Nehemia Setia N & 60 \\
12 & 1913043026 & Ikhsan Taufiq & 80 \\
13 & 1913043036 & Laila Wafiq Azizah & 60 \\
14 & 1913043041 & Anggun Trishia U H & 65 \\
15 & 1913043042 & Nyimas Sekartaji K & 60 \\
\hline
\end{tabular}


Based on table 1, it can be seen that a sample of 15 students with upo indicators varied widely in the distribution of values. It can be seen that the student with the highest score is 80 with quality letter $\mathrm{A}$. The lowest score is 60 with quality letter $\mathrm{C}+$. With an average of 66, 93 . Based on this, it can be seen that the students' ability to dance the rudat dance upo is quite good and must be continuously improved. Capacity building can be done by continuing to practice the Rudat dance movements regularly.

Table 2. Student scores with the Bagho indicator

\begin{tabular}{cclc}
\hline NO & NPM & \multicolumn{1}{c}{ NAME } & BAGHO \\
\hline 1 & 1913043001 & Indika Oktafiani & 63 \\
2 & 1913043002 & Elda Savira & 80 \\
3 & 1913043006 & Diana Mai Sari & 63 \\
4 & 1913043007 & Etika Witantri & 63 \\
5 & 1913043008 & Sairul Anwar & 62 \\
6 & 1913043009 & Ahmad Faisal Akbar & 80 \\
7 & 1913043011 & Retno Anisa Putri & 66 \\
8 & 1913043017 & Okta Berliana & 77 \\
9 & 1913043018 & Denta Pramana Putra & 78 \\
10 & 1913043021 & Rara Ardelia Artanti & 70 \\
11 & 1913043023 & Nehemia Setia N & 63 \\
12 & 1913043026 & Ikhsan Taufiq & 80 \\
13 & 1913043036 & Laila Wafiq Azizah & 62 \\
14 & 1913043041 & Anggun Trishia U H & 65 \\
15 & 1913043042 & Nyimas Sekartaji K & 62 \\
\hline
\end{tabular}

In table 2, it can be seen that students' dancing abilities with the bagho indicator. Based on the table, it can be seen that the highest value on bagho ability is 80 with the letter quality A. the lowest value is 62 with the quality letter $\mathrm{C}+$. With the average obtained, namely 68.93. Based on the scores listed in the table, it can be said that the students' dancing ability on the Bagho indicator is quite good and the average is higher than the UPO indicator. However, the meanri ability of students must continue to be improved by practicing.

Table 3. Student scores with the Ghaso indicator

\begin{tabular}{cclc}
\hline NO & NPM & \multicolumn{1}{c}{ NAME } & GHASO \\
\hline 1 & 1913043001 & Indika Oktafiani & 67 \\
2 & 1913043002 & Elda Savira & 74 \\
3 & 1913043006 & Diana Mai Sari & 63 \\
4 & 1913043007 & Etika Witantri & 70 \\
5 & 1913043008 & Sairul Anwar & 70 \\
6 & 1913043009 & Ahmad Faisal Akbar & 75 \\
7 & 1913043011 & Retno Anisa Putri & 70 \\
8 & 1913043017 & Okta Berliana & 74 \\
9 & 1913043018 & Denta Pramana Putra & 76 \\
10 & 1913043021 & Rara Ardelia Artanti & 70 \\
11 & 1913043023 & Nehemia Setia N & 65 \\
12 & 1913043026 & Ikhsan Taufiq & 80 \\
13 & 1913043036 & Laila Wafiq Azizah & 65 \\
14 & 1913043041 & Anggun Trishia U H & 67 \\
15 & 1913043042 & Nyimas Sekartaji K & 62 \\
\hline
\end{tabular}


Table 3 shows the students' dancing abilities with the ghaso indicator. Based on the table above, the highest score obtained by students is 80 with the letter quality A. The lowest score obtained by students is 62 with the letter quality $\mathrm{C}+$. The mean obtained by students on the Ghaso indicator is 69.86. Based on the value obtained according to the table above, the dancing ability of students on the Ghaso indicator is quite good with a higher average than Upo and Ghaso. This means that students have actually been able to harmonize the movements and the tempo and rhythm of the movements according to the characteristics of the Rudat dance.

\section{Conclusion}

The results of the development research that have been carried out can be concluded as follows:

In the preliminary study phase, it was found that the analysis of the implementation of the assessment of traditional Lampung dances so far still used Javanese dance assessment instruments, namely wiraga, wirama, and wirasa. Lecturers, teachers, and prospective cultural arts teacher students do not really know and understand the Lampung traditional dance assessment instruments, so it is necessary to do socialization regarding this matter. This limitation makes lecturers, teachers, and students still use Javanese indicators to this day.

The product that was developed was an assessment instrument for traditional Lampung dance which was seen by its application in the assessment of the Rudat dance, which is one of the traditional dances of Lampung. Based on the research that has been done, Lampung traditional dance instruments are very suitable to be used to assess Rudat dance. The upo, bagho, and ghaso indicators represent indicators to assess the dancing abilities of students. This can be seen from the results of the assessment using the Lampung indicator, which shows that student scores are varied with an even distribution.

The validation of the Lampung traditional dance assessment instrument was carried out through expert testing of content validity and construct validation. The results of the assessment obtained from expert validation state that this performance appraisal is appropriate for use as a form of assessment in Lampung traditional dance. However, the reliability test needs to be done to strengthen the traditional Lampung dance instruments that have been found. Thus, this assessment instrument can continue to experience improvement and can be used in all assessments of traditional Lampung dances and no longer "meminajm" Javanese indicators. In addition, the better and stronger the traditional dance assessment instruments in Lampung provide opportunities for the development of assessment instruments for Indonesian traditional dances and international dances.

Acknowledgments. I thank Allah SWT, Almighty God who gives health so that this article can be completed on time. Next, I would like to thank FKIP Unila as the organizer of ICOPE, who gave me the opportunity to join and write at this event. I also thank my family, husband and children who have been patient in writing this article, because of the time it took up during the completion of the article.

\section{References}

[1] Shara Marsita Mirdamiwati, Supriyadi, S. 2016. Pengembangan Instrumen Psikomotor Tari Selendang Pemalang Berbasis Android. Jurnal of Educational and Evaluation, 6(1), 10-18. 
[2] Habsary, D., \& Bulan, I. 2016. Evaluasi Pembelajaram Seni Tari Tradisional Lampung. Yogyakarta: Arttex.

[3] Sugiyono. 2018. Metode Penelitian Kombinasi (mixed Methods). In International Journal of Physiology.

[4] Nurgiyantoro, B. 2010. Penilaian pembelajaran sastra berbasis kompetensi. Yogyakarta: BPFE.

[5] Sudjana, Nana DR. 1989. Penilaian Hasil Proses Belajar Mengajar. Bandung: PT. Remaja Rosdakarya.

[6] Mirdamiwati, S. M. 2015. Pengembangan instrumen penilaian psikomotor tari kreasi siswa di smp berbasis IT.1-7. Sharamarsita@gmail.com

[7] Soedarsono. 1972. Jawa dan Bali. Yogyakarta.

[8] Bulan, I. 2019. Tari Melinting Tari Melinting di Masa Lalu dan Masa Kini. Jurnal Seni Tari. https://doi.org/10.15294/jst.v8i1.24899 